ks. Henryk Paprocki, Przyjazna wspótpraca i co dalej?, [w:] 0 co chodzi w ekumenizmie? Czym jest dialog? Podstawo-

we idee Vaticanum II pót wieku później, red. Marek Kita, Kraków 2015, s. 27-32.

DOI: http://dx.doi.org/10.15633/9788374384551.03

ks. Henryk Paprocki

\title{
Przyjazna współpraca i co dalej?
}

Nie trzeba w ogóle dowodzić, że w XX wieku dokonała się swoista rewolucyjna zmiana $\mathrm{w}$ relacjach między chrześcijanami. Zaczęła się w środowisku protestanckim w czasie I wojny światowej. Po tej wojnie do nowego ruchu, nazwanego ekumenicznym, dołączyło prawosławie. Osiągnięcia Komisji Wiary i Ustroju oraz Praktycznego Chrześcijaństwa są godne uwagi. Jednak prawdziwa zmiana dokonała się w 1964 roku, gdy Kościół rzymskokatolicki po przejściu trudnej drogi od potępienia dotarł do tego punktu, w którym afirmacja stała się nieunikniona. Niechęć, mówiąc oględnie, a niekiedy nienawiść, powoli zastępować zaczęły spotkania i przyjazne relacje. Można nawet mówić o entuzjazmie ekumenicznym lat sześćdziesiątych i siedemdziesiątych minionego wieku. Entuzjazm zaczął jednak powoli opadać. Przeciętny wierny oczekiwał szybkich decyzji, których nie było. Jestem skłonny twierdzić, że obecnie ekumenizm znajduje się w fazie kryzysu. Oficjalnie mamy do czynienia z „ekumenizmem okolicznościowym”, mającym charakter „wybuchowy” w miesiącu styczniu. Na nabożeństwach ekumenicznych są ciągle te same osoby, tyle że jest ich coraz mniej...

Cóż bowiem przeciętnemu wiernemu mówi krótka informacja, że „Mieszana Komisja Teologiczna Prawosławno-Rzymskokatolicka opracowała dokument o Kościele"? Dziesięć lat temu byliśmy dumni z podpisania w Polsce dokumentu uznającego wzajemnie chrzest, a pytano mnie: "Jak to, to dotychczas nie 
uznawaliśmy?” - „Uznawaliśmy” - „To cóż takiego niezwykłego jest w tym dokumencie?"

Widać wyraźnie, że mamy do czynienia z dwoma formami ekumenizmu: „ekumenizmem na górze” i „ekumenizmem na dole”. Komunikacja między tymi dwoma rodzajami ekumenizmu w praktyce jest żadna. Przez pojęcie „ekumenizmu na górze" rozumiem spotkania hierarchów, duchownych i teologów, zjazdy, sesje naukowe i konferencje. „Ekumenizm na dole” dotyczy wiernych. Hierarchie wartości obu tych grup są całkowicie różne. Dodatkowo grupa „na dole” jest zmęczona obecnym - w jej ocenie - brakiem postępu w ekumenizmie.

Wszyscy mają świadomość, że osiągnięto dużo, możemy mówić o przyjaznej współpracy Kościołów. Co dalej?

Nie chcę bawić się w proroka, ale to chyba wszystko. Pozostaje nam rozwijanie owej współpracy, gdyż zmiany doktrynalne prowadzące do jedności są po prostu nierealne. Raczej - jak Włodzimierz Sołowjow - możemy mówić o pojednaniu w obliczu zagrożenia przez Antychrysta, przy końcu dziejów. Przykład okresu międzywojennego świadczy dobitnie, że Komisja Praktycznego Chrześcijaństwa działała znakomicie, a Komisja Wiary i Ustroju zawsze miała problemy. Po II wojnie światowej nie widać w tym znaczących różnic. Nie oznacza to jednak, że należy załamać ręce i płakać. W 451 roku, czyli prawie 1600 lat temu, wydarzył się „cud Chalcedonu”, a jeszcze wcześniej, w 325 roku „cud Nicei”. Kościół jest zawsze w ręku Boga, jest bytem zależnym. Ten fakt powinien budzić nadzieję. Cud jedności nie zależy od nas. Natomiast my winniśmy zrobić wszystko, co w naszej mocy, żeby on nastąpił. Przywołam tu słowa Jezusa Chrystusa: „U ludzi jest to niemożliwe, ale u Boga wszystko jest możliwe" (Mt 19, 26). Być może będziemy musieli jeszcze przejść przez wiele doświadczeń, aby cud jedności mógł się dokonać. Skoro jednak - zgodnie z przysłowiem - „Pan Bóg pisze prosto na krzywych liniach”, trzeba być optymistą.

Przecież osiągnięto zdumiewająco wiele po tysiącu czy też pięciuset latach podziałów i wrogości. Być może z naszej perspektywy jest to ciągle za mało, ale w końcu trzeba patrzeć na wszystko, także na ekumenizm, „sub specie aeternitatis”. 
Powtarzam, że moja wizja ekumenizmu w Polsce jest pesymistyczna, co jednak nie znaczy, że jestem jego przeciwnikiem. Określiłem polski ekumenizm jako okazjonalny. Jesteśmy ewenementem pod tym względem w Europie. Jest to ekumenizm, który wybucha w styczniu, i to nie w całej Polsce (bo są jeszcze enklawy, gdzie tak nie jest), a nawet nie w całej Warszawie. Potem zamiera i znowu się ożywia, bo na przykład trzeba zorganizować jakaś konferencję ekumeniczną, trzeba być recenzentem jakiejś pracy naukowej w UKSW czy KUL, bądź w ChAT, i na tym właściwie ekumenizm w Polsce się kończy. Oczywiście, istnieją bardzo sympatyczne kontakty i ludzie o nastawieniu ekumenicznym, ale ogólna sytuacja w Polsce jest pod tym względem trudna, aczkolwiek powoli zmienia się na lepszą. Jak zresztą może być łatwa, skoro wszystko inne też jest trudne i skomplikowane.

Istnieją dwa mechanizmy, które rządzą ekumenizmem w Polsce: pierwszy to ciągle istniejący w szerokich masach wiernych (myślę, że we wszystkich Kościołach) pewien lęk. Ma on swoje uwarunkowania historyczne i psychologiczne, niemiłe doświadczenia z przeszłości rzutują bowiem na dzisiejsze postawy. Kiedyś działo się coś niedobrego, tu zburzyli cerkiew prawosławną, tam zamknęli kościół ewangelicki, nie wiadomo, co będzie dalej. Lepiej się więc nie angażować. Jeśli chodzi o drugi mechanizm, to posłużę się porównaniem do małej myszki i dużego kota. Wszystko, tylko nie z katolikami, bo oni nas połkną, a jeśli nie połykają, to zawsze jest obawa, że mogą to zrobić. Bo jeśli nas w jakiejś miejscowości jest 50 rodzin, a ich 10 tysięcy, to sytuacja jest oczywista: muszą nas połknąć. Takie myślenie sprawia, że uprawianie ekumenizmu nie jest łatwe. Poza tym nakładają się na siebie problemy o charakterze wyznaniowym i problemy o charakterze narodowościowym, o których coś wiem, bo mój Kościół jest Kościołem wielonarodowościowym. Wydaje mi się, że problemy narodowościowe dominują nad konfesyjnymi. Na przykład, pewne napięcia występują w okolicach Sejn - gdzie mieszkają wcale nie prawosławni, lecz katolicy Litwini - a także w okolicach Sokółki, gdzie z kolei część Białorusi- 
nów to też rzymscy katolicy. Owo napięcie nie przebiega między prawosławiem a Kościołem katolickim czy innym, lecz między jednym a drugim narodem. I coś z tym trzeba zrobić. Wielkim zadaniem wszelkich działaczy kościelnych jest tłumaczenie, czym jest tożsamość wyznaniowa, czym ekumenizm i jak się jedno ma do drugiego. Jest dużo zagrożeń w polskim ekumenizmie, a do tego dochodzi stagnacja odgórna. Ostatnio „szczyty" przejawiają małą aktywność ekumeniczną. Czy nie byłoby warto rozruszać „dołów”, skoro „szczyty” są oblodzone? W dolinach może być przecież piękna zieleń. A na dobrą sprawę nie bardzo wiemy, co jest w tych dolinach, może więc warto by było zejść do nich i zacząć od pracy oddolnej. Ekumenizm oficjalny w praktyce przynosi bowiem minimalne efekty. Nie jestem przeciwny badaniom naukowym, ale przede wszystkim trzeba dotrzeć do szerokich kręgów odbiorców i je uaktywnić. Póki patrzymy przez pryzmat Warszawy, gdzie jest i kościół św. Marcina, i kościół reformowany, gdzie się coś dzieje, gdzie jest prasa i Rada Ekumeniczna, gdzie prowadzone są dialogi i odbywają się spotkania - to odnosimy wrażenie, że nie jest tak źle. Ale popatrzmy na małe miasteczka i wsie - co tam się dzieje? Czy tam w ogóle coś się dzieje? Co zatem zrobić, żeby ekumenizm nie pozostawał tylko na szczytach, ale rozkwitał również w dolinach? Myślę, że bardzo wiele będzie zależało od inicjatyw oddolnych. Musimy starać się uaktywniać duchowieństwo parafialne. Posłużę się przykładem znanym w Warszawie od dawna, a mianowicie: w wolskiej parafii prawosławnej św. Jana Klimaka oraz w parafii rzymskokatolickiej św. Wawrzyńca od wielu już lat praktykowana jest 1 listopada wspólna - katolicko-prawosławna - procesja po cmentarzu. Jest ona wynikiem inicjatywy oddolnej proboszczów obu parafii, którzy dali dowód odwagi, nie patrząc bowiem na uwarunkowania historyczne, na brak takiej czy podobnej tradycji, dali początek nowej tradycji ekumenicznej. Dziś już prawdopodobnie ludzie w obu parafiach nie wyobrażają sobie, że mogłoby być inaczej. Potrzebna jest więc inicjatywa i odwaga na szczeblu parafialnym. Jeśli będziemy czekać na instrukcje i wypracowane metody, to może być tak, 
jak z instrukcją w sprawie małżeństw mieszanych, która kiedyś wzbudziła zastrzeżenia wszystkich stron, łącznie z tą, która ją wydała. Inicjatywy podejmowane na dole zawsze zaowocują i pozostaną w świadomości ludzi. Ekumenizm zrodził się jako ruch oddolny i jako taki był najpiękniejszy, a od momentu zinstytucjonalizowania wygląda już nieco inaczej. Dużą rolę z pewnością mogłaby w uaktywnieniu „dołów” odegrać prasa kościelna. Chciałem też zaznaczyć, że większość konfliktów międzywyznaniowych ma swe źródło w duchownych, a nie w wiernych. Wierni różnych Kościołów na ogół są zaprzyjaźnieni i nie trzeba tych relacji niszczyć.

Czy jednak w ogóle należy dążyć do „absolutnej jedności” w sprawach wiary? Pozwolę sobie przytoczyć pouczający przykład z historii Kościoła w pierwszym tysiącleciu. Chodzi mianowicie o paralelne drogi interpretacji myśli patrystycznej na Wschodzie (prawosławie) i na Zachodzie (katolicyzm), o czym znakomicie pisze Siergiej Chorużyj:

Chociaż oba nurty myśli chrześcijańskiej mają za swoje źródło klasyczną patrystykę IV wieku, to jednak już w pierwszych okresach swego rozwoju stały się odrębne. Już na przełomie IV i V wieku rodzi się szczególna zachodnia redakcja lub też gałąź patrystyki, która zyska swoją syntezę i charakterystyczne oblicze przede wszystkim w dziełach bł. Augustyna. Wśród głównych cech redakcji Augustyna należy podkreślić silny element platonizmu i neoplatonizmu, co odbiło się na teorii łaski i predestynacji, na traktowaniu wolności, zła i grzechu... Następny znaczący etap tradycji zachodniej, scholastyka, jest zwykle rozpatrywany jako radykalna zmiana i zwrot w charakterze dyskursu teologiczno-filozoficznego oraz w ukierunkowaniu jego ewolucji ${ }^{1}$.

Jednak te dwie redakcje, całkowicie różne, nie stanowiły żadnego problemu przez sześć wieków. Dopiero rodzący się ekskluzywizm wyznaniowy stał się bodźcem do uznania wyłącznie

1 S. Chorużyj, Czym jest myśl prawosławna, „Elpis” 3 (2001) z. 4, s. 104-104. 
własnej tradycji za prawdziwą i autentyczną, a każdej innej za błędną. Kościół pierwszych wieków był o wiele bardziej otwarty niż Kościół przełomu tysiącleci. Może należałoby wyciągnąć z tego faktu pewne wnioski.

Na zakończenie pozwolę sobie przytoczyć opinię ojca Pawła Florenskiego:

Nie wiążemy prawdy Prawosławia ani z określonymi miejscami hierarchicznymi, ani z tekstem określonych ksiąg, lecz wierzymy, że „Duch tchnie kędy chce”. Święci asceci, starcy, pneumatoforyczni mężczyźni i kobiety - oto żywi nosiciele Prawosławia - a wszystko inne to tylko zewnętrzne ogrodzenie...

Warto zastanowić się nad tym stwierdzeniem. 